\title{
Role of Ice Nucleation and Antifreeze Activities in Pathogenesis and Growth of Snow Molds
}

\author{
Christopher S. Snider, Tom Hsiang, Guiying Zhao, and Marilyn Griffith
}

First and fourth authors: Department of Biology, University of Waterloo, Waterloo, Ontario, N2L 3G1, Canada; and second and third authors: Department of Environmental Biology, University of Guelph, Guelph, Ontario, N1G 2W1, Canada. Accepted for publication 15 December 1999.

\begin{abstract}
Snider, C. S., Hsiang, T., Zhao, G., and Griffith, M. 2000. Role of ice nucleation and antifreeze activities in pathogenesis and growth of snow molds. Phytopathology 90:354-361.

We examined the ability of snow molds to grow at temperatures from -5 to $30^{\circ} \mathrm{C}$ and to influence the growth of ice through assays for ice nucleation and antifreeze activities. Isolates of Coprinus psychromorbidus (low temperature basidiomycete variant), Microdochium nivale, Typhula phacorrhiza, T. ishikariensis, $T$. incarnata, and $T$. canadensis all grew at $-5^{\circ} \mathrm{C}$, whereas Sclerotinia borealis and $S$. homoeocarpa did not grow at temperatures below $4^{\circ} \mathrm{C}$. The highest threshold ice nucleation tempera-

ture was $-7^{\circ} \mathrm{C}$. Because snow molds are most damaging to their hosts at temperatures above this, our results imply that the pathogenesis of these fungi is not dependent on ice nucleation activity to cause freeze-wounding of host plants. All snow molds that grew at subzero temperatures also exhibited antifreeze activity in the growth medium and in the soluble and insoluble hyphal fractions, with the exception of $M$. nivale and one isolate of T. canadensis. The lack of high ice nucleation activity combined with the presence of antifreeze activity in all fungal fractions indicates that snow molds can moderate their environment to inhibit or modify intraand extracellular ice formation, which helps explain their ability to grow at subzero temperatures under snow cover.
\end{abstract}

Snow molds can tolerate low temperatures and attack plants under snow cover (16). These fungi include psychrophilic organisms such as Coprinus psychromorbidus, Sclerotinia borealis (=Myriosclerotinia borealis), and Typhula spp. and low-temperature-tolerant organisms such as Microdochium nivale (formerly known as Fusarium nivale). Snow molds cause diseases in many overwintering plants worldwide (32) including evergreen trees, perennial grasses, and overwintering cereals. As their name suggests, snow molds require some duration of snow cover for pathogenic activity and visible effects on host plants, and often the severity of disease is proportional to the duration of continuous snow cover (16).

The snow molds T. ishikariensis, T. incarnata, and M. nivale, which are all serious plant pathogens, have been studied in detail (32), but relatively little is known about how these organisms cope with their freezing environments. While low temperatures may be beneficial to snow mold pathogenesis, they also impose stresses on the fungal pathogens because growth rates and many other physiological processes are slowed by cold (15).

How do snow molds continue to grow at freezing temperatures? One important characteristic of organisms that grow or are active at subzero temperatures is their ability to avoid freezing. Ice forms when the ambient temperature is below the freezing temperature of a solution and a seed crystal or other nucleator is present to initiate the crystallization process $(8,22)$. The mechanism of freezing avoidance involves accumulating solutes to depress the freezing temperature and producing antifreeze proteins (AFPs) that adsorb to the surfaces of ice to prevent its growth and to bind to ice nucleators $(3,4,6,19,31)$. By binding to ice, AFPs lower the freezing temperature but not the melting point of a solution, which is known as thermal hysteresis (35). Levels of thermal hysteresis range from 2 to $6^{\circ} \mathrm{C}$ in insects, 1 to $1.5^{\circ} \mathrm{C}$ in fish, 0.1 to $0.5^{\circ} \mathrm{C}$ in plants (35), 0.3 to $0.35^{\circ} \mathrm{C}$ in fungi, and 0.1 to $0.35^{\circ} \mathrm{C}$ in bacteria (7). In

Corresponding author: T. Hsiang; E-mail address: thsiang@uoguelph.ca

Publication no. P-2000-0214-01R

(C) 2000 The American Phytopathological Society the presence of AFPs, ice nucleation and the growth of ice are both inhibited, and the organism remains unfrozen or supercooled until the ambient temperature is lowered below the freezing temperature of the organism.

Freezing-tolerant organisms, such as some species of bacteria (24, $25)$, insects (6,38), amphibians (33), lichens (17), fungi (29), and plants (2), can initiate freezing by secreting ice nucleating substances outside of the cell or into intercellular spaces. Through this slow-freezing process, intracellular water is drawn outside of the cell, the contents of the cell are concentrated, and the cell avoids freezing (11), although cellular injury and death may still be caused by anoxia or dehydration $(23,34)$. The growth of extracellular ice crystals must still be limited to prevent physical damage to the cells. In freezing-tolerant insects and plants, AFPs play a crucial role in inhibiting recrystallization of smaller ice crystals into larger crystals that may cause physical damage $(18,20)$. Thus, the combination of ice nucleators and AFPs may work cooperatively in assisting freezingtolerant organisms to control ice formation: first, by adjusting the temperature and location at which ice forms and, secondly, by stabilizing the ice crystals at a relatively small size (13). Secreted ice nucleators play an important role in allowing freezing-tolerant organisms to survive low or prolonged subzero temperatures by minimizing the extent of supercooling, so that freezing becomes a relatively slow and controlled process (38).

For some epiphytic plant pathogens, ice nucleation serves to initiate freezing in susceptible plants, thus facilitating bacterial and fungal invasion of the tissues and increasing their access to nutrients $(24,29)$. Ice nucleation activity may also provide an ecological advantage for fungi and lichens by drawing in and storing water from surrounding environments $(17,29)$, thus providing water for fungal spores to germinate or hyphae to grow upon ice melt.

AFPs have been discovered in a wide range of overwintering organisms including marine teleost fishes, terrestrial arthropods, vascular and nonvascular plants, bacteria, and fungi $(4,7,12,27)$. It is not certain how AFPs function in fungi, although the activity of snow molds at subzero temperatures suggests that they must possess some type of freezing resistance. Previous work on antifreeze 
activity in fungi is very limited. Duman and Olsen (7) found thermal hysteresis activity in fruit body extracts of Pleurotus ostreatus, Flammulina velutipes, Coriolus versicolor, and a Stereum species collected in late winter; but there was no activity from fruit bodies collected in mid-summer. Protease treatment of the Coriolus versicolor extract eliminated thermal hysteresis activity (7). Newsted et al. (27) found proteins in snow molds (T. incarnata, S. borealis, and $C$. psychromorbidus) with epitopic homology to winter flounder AFP; however, the proteins were not characterized further.

The goal of our research was to determine how several snow molds are adapted to their low-temperature environments where they have to contend with ice formation, water deficits, and other physicochemical barriers to growth. We hypothesized that ice nucleation and antifreeze activity might contribute to pathogenesis and survival of low-temperature fungi. Our specific objectives were to characterize the temperature ranges for growth of several snow molds, to assess the relative importance of ice nucleation and antifreeze activities for these fungi, and then to determine whether proteins were responsible for these activities.

\section{MATERIALS AND METHODS}

Fungal isolates. The snow mold species selected for this study included $C$. psychromorbidus, $M$. nivale, T. phacorrhiza, T. incarnata, T. ishikariensis, T. canadensis, and S. borealis. M. nivale causes pink snow mold on overwintering grasses and is able to induce extensive disease without snow cover (32). T. incarnata requires a continuous snow cover exceeding 60 days to cause severe grey snow mold disease, and T. ishikariensis, including the variant T. canadensis, requires more than 90 days of snow cover (16). $T$. phacorrhiza is commonly found on overwintered corn residues, but has been reported to cause snow mold injury to winter wheat (30). More recently, it has been used successfully as an antagonist of grey snow mold in field tests (37). S. borealis causes snow mold on overwintering cereals and perennial grasses in Scandinavia, northern Asia, and the northern Canadian prairies (32). C. psychromorbidus causes cottony snow mold on overwintering grasses in both low- and high-snowfall regions across the Canadian prairies (32). Based on DNA markers and lack of con-specificity, certain isolates that have been named $C$. psychromorbidus should be called low temperature basidiomycete (LTB) until their taxonomic position is clarified (21). The two isolates named C. psychromorbidus in this study belong to the LTB grouping.

According to Smith et al. (32), these fungi are all psychrophilic because they can grow at $0^{\circ} \mathrm{C}$, although they exhibit a range of in vitro growth temperature optima from 8 to $20^{\circ} \mathrm{C}$. In addition, the mesophile $S$. homoeocarpa, which attacks turfgrass during the summer, was included in our study for comparison. All isolates were from southwestern Ontario, except for C. psychromorbidus from Alberta, $S$. borealis from Saskatchewan, and T. canadensis from British Columbia. Two isolates of each species were used in the following experiments.

Temperature optima. Growth temperature optima were determined using 9-cm-diameter plates containing $15 \mathrm{ml}$ of either $2 \%$ malt agar or Czapek-Dox agar (5) at a series of temperatures $(-5$, $0,4,10,14,22$, and $30^{\circ} \mathrm{C}$ ) for up to 4 weeks. Glycerol $(5 \%)$ was included in all media, specifically to prevent freezing when incubated at $-5^{\circ} \mathrm{C}$. The center of each plate was inoculated with a 5-mmdiameter agar plug from the edge of an actively growing colony, with three replicate plates for each isolate at each temperature. The limit of mycelial growth was marked weekly for 4 weeks and the distance from the edge of the agar plug recorded. Due to varying rates of establishment and the slow growth rate of certain isolates, the first week of growth was not included in analysis except for temperature-isolate combinations showing fast growth. For very slow-growing isolates, data from the next 3 weeks of growth were analyzed. For fast-growing isolates, only the growth during the first week was analyzed. The data were subjected to analysis of variance, and when significant differences between isolates were found, the means were separated by the test of least significant difference (LSD) $(P=0.05)$.

Fractions of fungal cultures. A 5-mm-diameter plug taken from the edge of an actively growing fungal colony on malt extract agar was inoculated into $50 \mathrm{ml}$ of $2 \%$ malt extract broth in a $250-\mathrm{ml}$ flask. Two 250-ml flasks were inoculated per isolate. The cultures were incubated with shaking $(140 \mathrm{rpm})$ at $4^{\circ} \mathrm{C}$. After 4 weeks, the cultures were harvested by vacuum filtration using Whatman no. 1 filter paper (Whatman International, Ltd., Maidstone, England) to separate the hyphae from the medium. The filtrate was stored at $-20^{\circ} \mathrm{C}$ until analysis. The fungal hyphae were washed twice with cold $0.5 \mathrm{M}$ $\mathrm{NaCl}$ by vortexing the hyphae and then centrifuging the sample at $12,000 \times g$ for $15 \mathrm{~min}$ at $4^{\circ} \mathrm{C}$ to separate the hyphae from the wash solution. The hyphae were then rinsed twice with deionized distilled water. The washed hyphal pellet was homogenized in an equal volume of deionized distilled water using a Polytron (PowerGen 125 homogenizer; Fisher Scientific, Ottawa, Ontario, Canada). To ensure breakage, the hyphae were sonicated using a Branson Sonifier Cell Disruptor 200 (Cleaning Technology Company, Trenton, NJ) set at a $60 \%$ duty cycle and output 5 . The hyphal fragments were centrifuged at $12,000 \times g$ for 30 min to separate a soluble fraction enriched with intracellular material and an insoluble fraction enriched with fragmented membranes, organelles, and cell walls. The insoluble fraction was resuspended in an equal mass of deionized distilled water, and both were stored at $-20^{\circ} \mathrm{C}$ until analysis.

Ice nucleation assay. Ice nucleation activity was assayed by the frozen-droplet technique (36) using a freezing plate (Thermoelectric cold plate TCP-6; Thermoelectrics Unlimited Inc., Wilmington, DE). The plate was modified by placing a copper plate on top of the aluminum plate using thermal grease (silicon vacuum grease with $5 \%[\mathrm{wt} / \mathrm{wt}]$ zinc oxide) to provide even thermal conductivity with only a $0.1^{\circ} \mathrm{C}$ difference across the surface of the plate. The copper plate was coated with STP oil treatment (First Brands, Canada Corp., Scarborough, Ontario, Canada) and overlaid by a layer of aluminum foil coated evenly with Vaseline petroleum jelly. When the plate had cooled to $10^{\circ} \mathrm{C}$, the samples were loaded as $2-\mu$ droplets. Deionized distilled water droplets and aliquots from uninoculated culture medium were used as controls. The plate temperature was lowered gradually with additional chilling provided by a cooling bath (Neslab LT-50DD; Neslab Instruments Inc., Newington, $\mathrm{NH}$ ), and the number of frozen droplets in each sample was recorded at $1^{\circ} \mathrm{C}$ intervals until all droplets had frozen. The temperature at which the first of 10 replicate droplets froze was defined as the threshold temperature for ice nucleation. Each set of 10 droplets was replicated three times per isolate. The threshold temperatures were subjected to analysis of variance, and when significant differences between isolates were found, the means were separated by the test of $\operatorname{LSD}(P=0.05)$.

Antifreeze assay. The antifreeze assay (12) was performed on the growth medium, the soluble hyphal fraction, and the insoluble hyphal fraction, with deionized distilled water and uninoculated culture medium used as controls. Ice crystal growth was viewed using a nanoliter osmometer (Clifton Technical Physics, Hartford, NY) with the freezing module mounted on the stage of a phase contrast light microscope (Olympus BH-2; Carsen Medical and Scientific Company Ltd., Markham, Ontario, Canada). The samples were flash frozen and then allowed to melt until a single ice crystal remained in the solution. The crystal was grown by slowly lowering the temperature, and the temperature range over which the crystal remained stable was recorded as the thermal hysteresis, using the conversion of 1,000 mosmol equivalent to a freezing point depression of $1.86^{\circ} \mathrm{C}$. Images of the crystals under the microscope were recorded using a JVC model GXS700U video camera (JVC Company of America, Wayne, NJ) and a Sony UP-870MD video graphic printer (Sony Corporation, Tokyo). In deionized distilled water, ice crystals grow along the $a$-axes as flat, circular disks (11). With low antifreeze activity, ice crystals formed hexagonal shapes as growth is in- 
hibited along the $a$-axes, while, with high antifreeze activity, the crystals grow along the $c$-axis to form three-dimensional shapes that remain stable even when the temperature is lowered further. These activities have been correlated with low and high concentrations of AFPs, respectively (3).

Heat denaturation and protease treatments. To determine whether proteins were responsible for antifreeze activity, 100- $\mu 1$ samples of malt extract culture media from $T$. phacorrhiza isolate Tp94614 were incubated at four different temperatures $(37,49,60$, and $100^{\circ} \mathrm{C}$ ) for up to $3 \mathrm{~h}$. Samples were treated with $3 \mathrm{mg}$ of proteinase K (Sigma Chemical Co., St. Louis) per $\mathrm{ml}$ at $37^{\circ} \mathrm{C}$ for $2 \mathrm{~h}$, at $49^{\circ} \mathrm{C}$ for $3 \mathrm{~h}$, and at $60^{\circ} \mathrm{C}$ for $1 \mathrm{~h}$; with $3 \mathrm{mg}$ of chymotrypsin (Sigma Chemical Co.) per $\mathrm{ml}$ at $37^{\circ} \mathrm{C}$ for $3 \mathrm{~h}$; and with $10 \mathrm{mg}$ of sodium dodecyl sulfate (SDS) (sodium lauryl sulfate; Fisher Scientific) per $\mathrm{ml}$ at $37^{\circ} \mathrm{C}$ for $3 \mathrm{~h}$. The treated samples were then assayed for antifreeze activity as described above.

\section{RESULTS}

Growth temperature optima. Growth temperature optima differed among snow molds and among isolates (Figs. 1 and 2). In most cases, the protected LSD values $(P=0.05)$ for isolate growth at each temperature were less than $0.2 \mathrm{~cm}$ per week (Figs. 1 and 2), indicating low variation within each species. The growth results on $2 \%$ malt agar (Fig. 1), which is a rich medium, were very similar to those on Czapek-Dox agar (Fig. 2), which is a defined minimal medium. The greatest differences between growth on the two media were for the Typhula spp., which generally showed a strong peak of growth at $4{ }^{\circ} \mathrm{C}$ on Czapek-Dox, while growth on malt was often greater at a higher temperature. All Typhula spp. were able to grow at $-5^{\circ} \mathrm{C}$ and generally had lower growth temperature optima (4 or $10^{\circ} \mathrm{C}$ ) than did the other four species. C. psychromorbidus and $M$. nivale showed slight growth at $-5^{\circ} \mathrm{C}$, with maximum growth at 14 and $22^{\circ} \mathrm{C}$, respectively. Neither of these two fungi nor the Typhula spp. showed any growth at $30^{\circ} \mathrm{C}$. The two Sclerotinia spp. did not grow at $-5^{\circ} \mathrm{C}$, exhibited barely noticeable growth at $0^{\circ} \mathrm{C}$, and their growth temperature optima were around or above $22^{\circ} \mathrm{C}$ with good growth even at $30^{\circ} \mathrm{C}$.

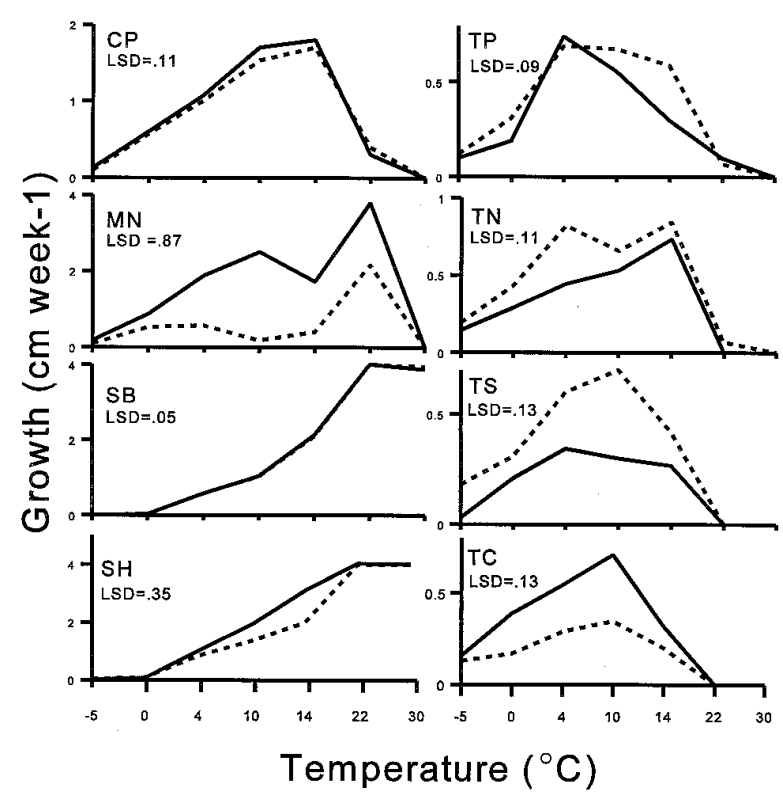

Fig. 1. Growth of eight fungal species on $2 \%$ malt extract agar at seven different temperatures with two isolates per species represented by solid and dotted lines $(\mathrm{CP}=$ Coprinus psychromorbidus, $\mathrm{MN}=$ Microdochium nivale, $\mathrm{SB}=$ Sclerotinia borealis, $\mathrm{SH}=S$. homoeocarpa, $\mathrm{TP}=$ Typhula phacorrhiza, $\mathrm{TN}=T$. incarnata, $\mathrm{TS}=T$. ishikariensis, and $\mathrm{TC}=T$. canadensis . Each point is the mean of three replicates per isolate, and LSD is the pooled least significant difference $(P=0.05)$ for all growth data of each species.
Ice nucleation activity. Out of 16 types of spent growth medium, 13 means were significantly higher for ice nucleation temperatures than that for the uninoculated control (Table 1). For the insoluble fraction, six means were higher, and for the soluble fraction, 11 means. The highest ice nucleation temperature of $-7.0^{\circ} \mathrm{C}$ was found in the insoluble fraction of $C$. psychromorbidus isolate Cp98061. The soluble fractions of $C$. psychromorbidus isolate Cp98060 and M. nivale isolate Mn96008 exhibited threshold ice nucleation temperatures of $-7.3^{\circ} \mathrm{C}$. All other ice nucleation temperatures were below $-8.3^{\circ} \mathrm{C}$. All isolates, including the mesophile $S$. homoeocarpa, showed some ice nucleation activity significantly greater than that of the uninoculated control in at least one of the three fractions.

Antifreeze activity. Isolates of Typhula spp. showed antifreeze activity in the growth medium and the soluble and insoluble hyphal fractions by both crystal modification (Table 1; Fig. 3) and thermal hysteresis. While most samples showed thermal hysteresis of 0.01 to $0.05^{\circ} \mathrm{C}$, a few samples such as the soluble fraction of T. ishikariensis isolate Ts 94069 had values up to $0.25^{\circ} \mathrm{C}$. The antifreeze activity exhibited by the insoluble fractions of T. phacorrhiza, T. incarnata, T. ishikariensis (Fig. 3), and T. canadensis all yielded star-shaped crystals. Crystals produced from growth medium fractions of T. phacorrhiza began as small hexagonal columns and expanded along the $c$-axis so that they resembled a chain of beads. These crystals grew by adding layer on top of layer of ice onto the original prism, slowly expanding out along the $a$-axis and then along the $c$-axis (Fig. 4). Some star-shaped crystals of $T$. ishikariensis also grew upward along the $c$-axis, adding ice crystals to the top surface of the crystal giving the star a three-dimensional surface. This third dimension showed as ridges centered along the arms of each star that met at the center of the star (Fig. 4).

C. psychromorbidus isolates showed antifreeze activity in the growth medium and the insoluble fraction. C. psychromorbidus formed ice crystals that began as hexagons, but formed star shapes with rounded points. When the $C$. psychromorbidus crystals grew further, they expanded along the $a$-axis, adding ice crystals only to the edges of the crystal (Fig. 4). There was no antifreeze activity observed in fractions from the following species: $M$. nivale, $S$.

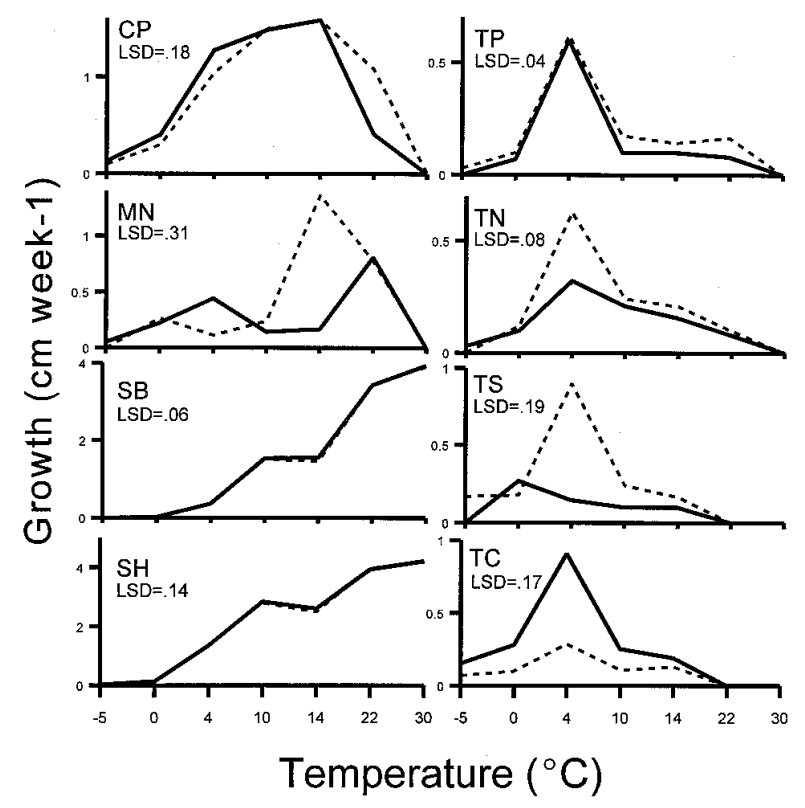

Fig. 2. Growth of eight fungal species on Czapek-Dox agar at seven different temperatures with two isolates per species represented by solid and dotted lines $(\mathrm{CP}=$ Coprinus psychromorbidus, $\mathrm{MN}=$ Microdochium nivale, $\mathrm{SB}=$ Sclerotinia borealis, $\mathrm{SH}=S$. homoeocarpa, $\mathrm{TP}=$ Typhula phacorrhiza, $\mathrm{TN}=$ T. incarnata, $\mathrm{TS}=T$. ishikariensis, and $\mathrm{TC}=T$. canadensis . Each point is the mean of three replicates per isolate, and LSD is the pooled least significant difference $(P=0.05)$ for all growth data of each species. 
borealis, and $S$. homoeocarpa, or in isolate Tc95109 of T. canadensis. All ice crystals formed in the uninoculated culture medium (malt extract broth) or from growth medium or hyphal fractions of these fungal isolates were circular (Fig. 3).

Protein treatments. Samples of malt extract growth medium from T. phacorrhiza isolate Tp94614 were treated to determine whether the antifreeze activity was associated with proteins. Heat treatments designed to denature proteins, including incubation at $60^{\circ} \mathrm{C}$ for $1 \mathrm{~h}$ or $100^{\circ} \mathrm{C}$ for $2 \mathrm{~min}$, eliminated antifreeze activity (Fig. 5). Protease treatments of fungal growth medium at room temperature had no effect on antifreeze activity. In contrast, treating the samples with proteinase $\mathrm{K}$ at $37^{\circ} \mathrm{C}$ for $2 \mathrm{~h}$ greatly decreased antifreeze activity, and incubating the samples in proteinase $\mathrm{K}$ at 49 or $60^{\circ} \mathrm{C}$ completely eliminated antifreeze activity (Fig. 5). Media samples incubated at 37 or $49^{\circ} \mathrm{C}$ for up to $3 \mathrm{~h}$ in the absence of proteases did not lose antifreeze activity (Fig. 5). Incubating samples in SDS at $37^{\circ} \mathrm{C}$ for $3 \mathrm{~h}$ also eliminated activity, while strong antifreeze activity was maintained after incubation in chymotrypsin at $37^{\circ} \mathrm{C}$ for $3 \mathrm{~h}$ (Fig. 5).

\section{DISCUSSION}

Growth temperatures. We examined seven different snow mold species that are able to cause disease under snow cover. The cardinal growth temperatures (minimum, optimum, and maximum) for our snow mold isolates (Figs. 1 and 2) are similar to what has been previously reported for $C$. psychromorbidus $\left(-4,15\right.$, and $\left.26^{\circ} \mathrm{C}\right), M$. nivale $\left(0,18\right.$, and $\left.30^{\circ} \mathrm{C}\right), T$. incarnata $\left(-5,11\right.$, and $\left.22^{\circ} \mathrm{C}\right)$, and varieties of $T$. ishikariensis including $T$. canadensis (-7, 10, and $20^{\circ} \mathrm{C}$ ) (32). Our isolates of $S$. borealis seem atypical in having much higher cardinal temperatures than those previously reported $(-7,8$, and $20^{\circ} \mathrm{C}$ ) (32), and more isolates of this species should be tested to confirm these results.

Growth at and below $0{ }^{\circ} \mathrm{C}$ is necessary for snow mold pathogens. Under as little as $10 \mathrm{~cm}$ of snow cover on a soil near Hamilton, Ontario, Canada, the temperature at the soil surface remained close to $0^{\circ} \mathrm{C}(28)$. In central Alberta, average snow depths of 32 to $35 \mathrm{~cm}$ for snow cover durations of around 150 days prevented temperatures at $5-\mathrm{cm}$ soil depths from decreasing below $-5^{\circ} \mathrm{C}$, even when air temperatures were near $-40^{\circ} \mathrm{C}$ (9). This insulating layer provides protection from extremely cold temperatures and main- tains a stable environment (10). Although they are capable of growing at temperatures above 5 to $10^{\circ} \mathrm{C}$, snow molds such as $T$. incarnata and T. phacorrhiza lose their competitive advantage in the field to mesophilic fungi and to an increased ability of the host plants to grow and defend themselves against pathogens (16). The greatest pathogenic activity by snow molds is found under heavy snow cover, and the highest degree of host plant injury is correlated with the longest duration of the snow cover $(16,32)$ as carbohydrate reserves are depleted (26).

Ice nucleation activity. Fungal ice nucleation activity may cause wounding of plants tissues by initiating freezing at higher temperatures (1), much like the mechanism reported for epiphytic ice nucleation-active bacteria that initiate freezing in annual plants during a light frost (24). Although previous studies of ice nucleation activity in fungi such as lichen mycobionts and Fusarium spp. reported threshold ice nucleation temperatures as high as $-1.9^{\circ} \mathrm{C}(1)$, the highest ice nucleation temperature observed in our study was $-7.0^{\circ} \mathrm{C}$, which reflects a low level of ice nucleation activity. Furthermore, our results indicated that these snow molds do not secrete ice nucleators with a high threshold ice nucleation temperature, nor do they assemble highly active ice nucleators upon their cell walls as has been described for ice nucleation-active bacteria (14).

One isolate of the mesophile $S$. homoeocarpa had a threshold ice nucleation temperature of $-9.0^{\circ} \mathrm{C}$ in the insoluble fraction. This fungus is not pathogenic at subzero temperatures and shows negligible growth at $0^{\circ} \mathrm{C}$. Because the threshold ice nucleation temperatures of the insoluble and medium fractions of snow molds were below the freezing point $\left(-5^{\circ} \mathrm{C}\right)$ of their host plants (2) and, in most cases, not significantly higher than that of the mesophile, ice nucleation activity is probably unimportant for growth and pathogenesis of the snow molds studied here and, perhaps, for other fungi that are active under snow cover. Instead, the low level of ice nucleation activity probably reflects a strategy of freezing avoidance at temperatures greater than $-7^{\circ} \mathrm{C}$ by snow molds protected by snow cover.

Antifreeze activity. Isolates of Typhula spp., except for $T$. canadensis isolate Tc95109, showed antifreeze activity in all fractions. The insoluble fraction of most Typhula spp. produced unusual star-shaped crystals by initially forming hexagons that grew along the $a$-axis at the corners of the hexagons to form six-pointed stars. In contrast, crystals grown in solutions of fish AFPs form hexagonal

TABLE 1. Ice nucleation and antifreeze activity in several species of snow molds and the mesophile Sclerotinia homoeocarpa ${ }^{\mathrm{a}}$

\begin{tabular}{|c|c|c|c|c|c|c|c|}
\hline \multirow[b]{2}{*}{ Species } & \multirow[b]{2}{*}{ Isolate } & \multicolumn{3}{|c|}{ Ice nucleation temperature $\left({ }^{\circ} \mathrm{C}\right)^{\mathrm{b}}$} & \multicolumn{3}{|c|}{ Antifreeze activity ${ }^{c}$} \\
\hline & & Insoluble & Soluble & Medium & Insoluble & Soluble & Medium \\
\hline Coprinus psychromorbidus ${ }^{\mathrm{d}}$ & Cp98061 & -7.0 & -8.0 & -9.3 & + & + & + \\
\hline C. psychromorbidus ${ }^{\mathrm{d}}$ & Cp98060 & -9.7 & -7.3 & -11.0 & + & + & + \\
\hline Sclerotinia borealis & Sb98233 & -11.7 & -9.0 & -9.7 & - & - & - \\
\hline S. borealis & Sb98232 & -10.7 & -8.7 & -10.3 & - & - & - \\
\hline S. homoeocarpa & Sh96413 & -9.0 & -11.3 & -9.7 & - & - & - \\
\hline S. homoeocarpa & Sh96414 & -14.0 & -13.3 & -10.0 & - & - & - \\
\hline Typhula canadensis & Tc95108 & -10.0 & -11.7 & -9.3 & + & + & + \\
\hline T. canadensis & Тc95109 & -12.0 & -11.7 & -10.0 & - & - & - \\
\hline T. incarnata & Tinc46 & -13.0 & -9.3 & -10.0 & + & + & + \\
\hline T. incarnata & Tinc 21 & -12.7 & -8.3 & -11.3 & + & + & + \\
\hline T. ishikariensis & Ts94069 & -12.3 & -11.7 & -10.7 & + & + & + \\
\hline T. ishikariensis & Ts 94070 & -14.0 & -11.7 & -11.3 & + & + & + \\
\hline T. phacorrhiza & Tp94614 & -13.3 & -10.0 & -12.0 & + & + & + \\
\hline T. phacorrhiza & Tp94671 & -14.0 & -8.3 & -13.0 & + & + & + \\
\hline Microdochium nivale & Mn96008 & -11.3 & -7.3 & -11.7 & - & - & - \\
\hline M. nivale & Mn96103 & -10.7 & -10.0 & -12.0 & - & - & - \\
\hline $2 \%$ Malt extract broth & & -13.0 & -13.0 & -13.0 & & & - \\
\hline Distilled water & & -13.0 & -12.3 & -12.7 & & & - \\
\hline Least significant difference $(P=0.05)$ & & 1.83 & 1.52 & 1.29 & & & \\
\hline
\end{tabular}

a Assay procedures are described in text.

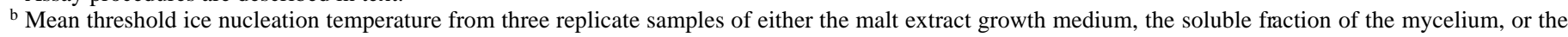
insoluble fraction.

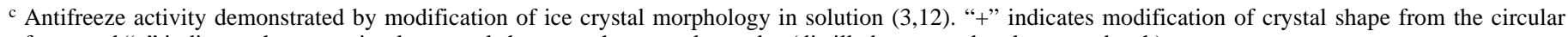
form; and "-" indicates the same circular crystal shapes as the control samples (distilled water and malt extract broth).

$\mathrm{d}$ These isolates originally identified as Coprinus psychromorbidus are more properly called low temperature basidiomycete (LTB). 


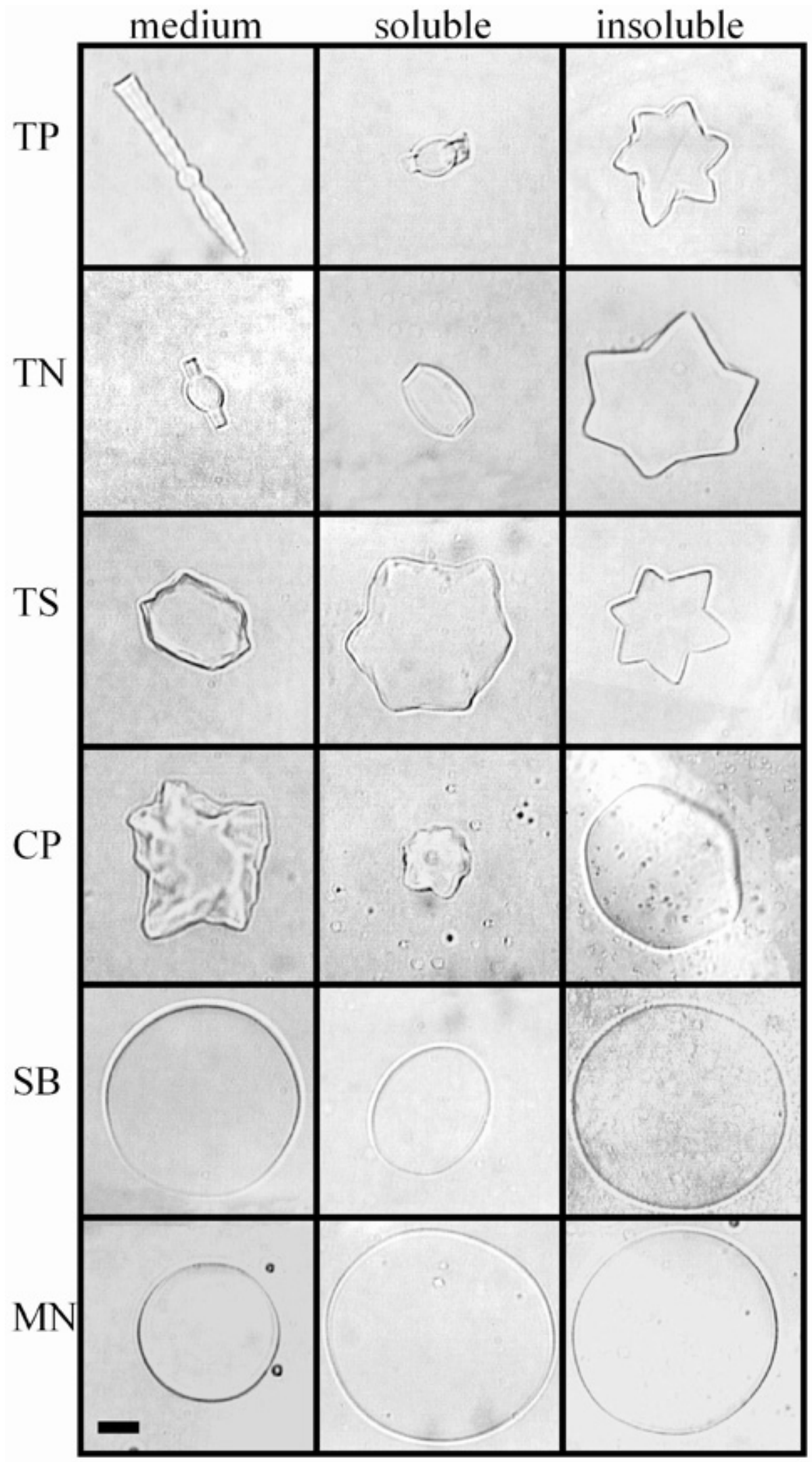

Fig. 3. Ice crystals formed in fractions of different snow molds $(\mathrm{TP}=$ Typhula phacorrhiza isolate $\mathrm{Tp} 94671, \mathrm{TN}=T$. incarnata isolate Tn46 or Tn21, TS $=T$. ishikariensis isolate Ts94070 or Ts94069, $\mathrm{CP}=$ Coprinus psychromorbidus isolate $\mathrm{Cp} 98060$ or Cp98061, $\mathrm{SB}=$ Sclerotinia borealis isolate Sb98232, and MN = Microdochium nivale isolate $\mathrm{Mn} 96103)$. The medium was a filtrate of 4 -week-old shake cultures grown at $4^{\circ} \mathrm{C}$. Other fractions were obtained from $\mathrm{NaCl}-$ washed hyphae that was homogenized with a Polytron, sonicated with a cell disrupter, and separated by centrifugation into soluble (intracellular materials) and insoluble components (fragmented membranes, organelles, and cell walls). In pure water, ice crystals form as round disks, but antifreeze proteins bind to the surface of ice and produce crystal shapes that are hexagonal when viewed from the basal plane. The $c$-axis is normal to the plane of the page except in TP and $\mathrm{TN}$ medium and soluble fractions where the $c$-axis is parallel to the plane of the page. Magnification bar at lower left represents $10 \mu \mathrm{m}$. 
bipyramids, as growth along the $a$-axis is inhibited and the crystals grow along the $c$-axis (3). The chain of beads from the medium fraction of $T$. phacorrhiza and the ridged three-dimensional star shapes of $T$. ishikariensis are not typical of the ice modification observed in solutions of fish AFPs (3) or in plant AFPs (12).

We detected antifreeze activity in several isolates and found a correlation between detectable antifreeze activity and the optimum

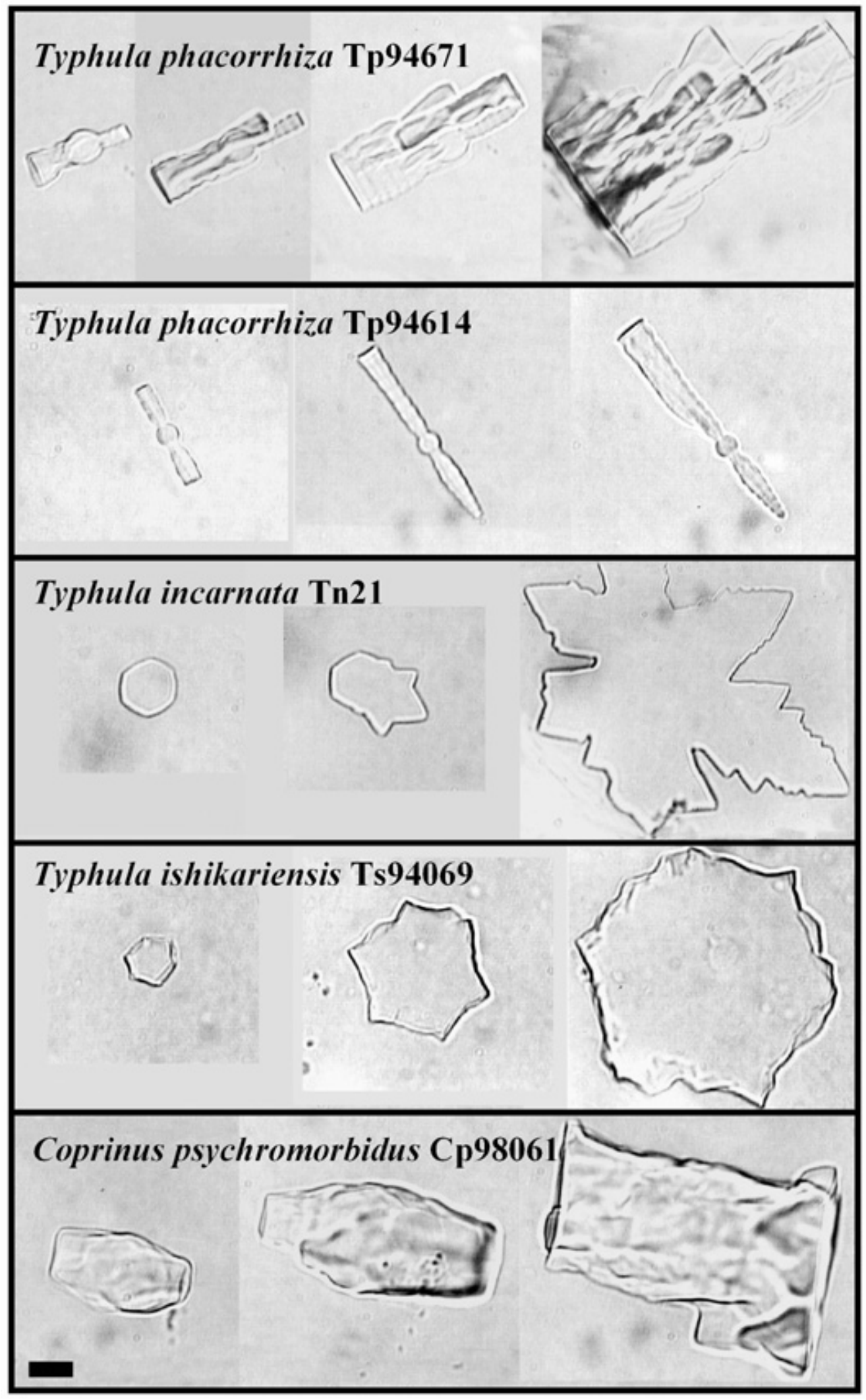

Fig. 4. Progressive growth of ice crystals in extracts from several snow molds. Each sample was flash frozen with a freezing module of a nanoliter osmometer and then allowed to melt until a single ice crystal remained in the solution. The crystal was then grown by slowly lowering the temperature and photographed over time as shown from left to right. The crystals from Typhula phacorrhiza and Coprinus psychromorbidus are presented with the $c$-axis parallel to the plane of the page. All other crystals are shown with the $c$-axis normal to the plane of the page. Magnification bar at lower left represents $10 \mu \mathrm{m}$. 
growth temperature of snow molds: no antifreeze activity was found in isolates with peak growth temperatures above $14^{\circ} \mathrm{C}(M$. nivale, $S$. borealis, and $S$. homoeocarpa), whereas antifreeze activity was detected in isolates with peak growth temperatures at 4, 10 (Typhula species), or $14^{\circ} \mathrm{C}$ (C. psychromorbidus), except for one isolate of $T$. canadensis. There was no correlation between antifreeze activity and threshold ice nucleation temperatures.

Extracellular and intracellular antifreeze activity may allow some fungi to be active at subzero temperatures and slow the growth of ice once crystallization does occur. Fungi require an aqueous environment for growth and pathogenesis to secrete enzymes and take up nutrients and food. Moreover, antifreeze activity may be essential for inhibiting the recrystallization of ice and promoting fungal survival during the many freeze-thaw cycles in winters with minimal snow cover. In addition to preventing hyphae from freezing at temperatures just below zero, AFPs produced by fungi may also keep host plant tissues from freezing, because frozen host tissues are unavailable as food.

The antifreeze activity found in growth medium of $T$. phacorrhiza isolate Tp94614 was shown to arise from protein molecules, because the activity was lost under conditions that promote the denaturation or degradation of proteins. The ice crystal structures associated with the snow mold species showed growth patterns different from those previously observed, which suggests that these AFPs may bind to different planes of the ice crystal lattice than those found with AFPs from fish, insects, and plants. Further research to characterize the AFPs from snow molds can reveal the nature of their interaction with ice, elucidate their role in low-temperature survival, and define evolutionary relationships between AFPs of the diverse fungi known as snow molds.

\section{ACKNOWLEDGMENTS}

Funding for this study was provided by the Natural Sciences and Engineering Research Council of Canada, the Canadian Turfgrass Research Foundation, and Nu-Gro Corporation. Isolates of Coprinus psychromorbidus now known to be LTB were provided by A. Laroche, Agriculture Canada, Lethbridge, and isolates of Typhula canadensis and Sclerotinia borealis were provided by B. Gossen, Agriculture Canada, Saskatoon.

\section{LITERATURE CITED}

1. Ashworth, E. N., and Kieft, T. L. 1995. Ice nucleation activity associated with plants and fungi. Pages 137-162 in: Biological Ice Nucleation and Its Applications. R. E. Lee, Jr., G. J. Warren, and L. V. Gusta, eds. The American Phytopathological Society, St. Paul, MN

2. Brush, R. A., Griffith, M., and Mlynarz, A. 1994. Characterization and quantification of intrinsic ice nucleators in winter rye (Secale cereale) leaves. Plant Physiol. 104:725-735.

3. DeVries, A. L. 1986. Antifreeze glycopeptides and peptides: Interactions with ice and water. Methods Enzymol. 127:293-303.

4. DeVries, A. L. 1988. The role of antifreeze glycopeptides and peptides in the freezing avoidance of Antarctic fishes. Comp. Biochem. Physiol. 90B:611-621.

5. Dhingra, O. D., and Sinclair, J. B. 1995. Basic Plant Pathology Methods, 2nd ed. CRC Lewis Publishers, Boca Raton, FL.

6. Duman, J. G. 1982. Insect antifreezes and ice nucleating agents. Cryobiology 19:613-627.

7. Duman, J. G., and Olsen, M. T. 1993. Thermal hysteresis protein activity in bacteria, fungi, and phylogenetically diverse plants. Cryobiology 30 : 322-328.

8. Franks, F. 1985. Biophysics and Biochemistry at Low Temperature. Cambridge University Press, Cambridge.

9. Gaudet, D. A., Bhalla, M. K., Clayton, G. W., and Chen, T. H. H. 1989. Effect of cottony snow mold and low temperatures on winter wheat sur-

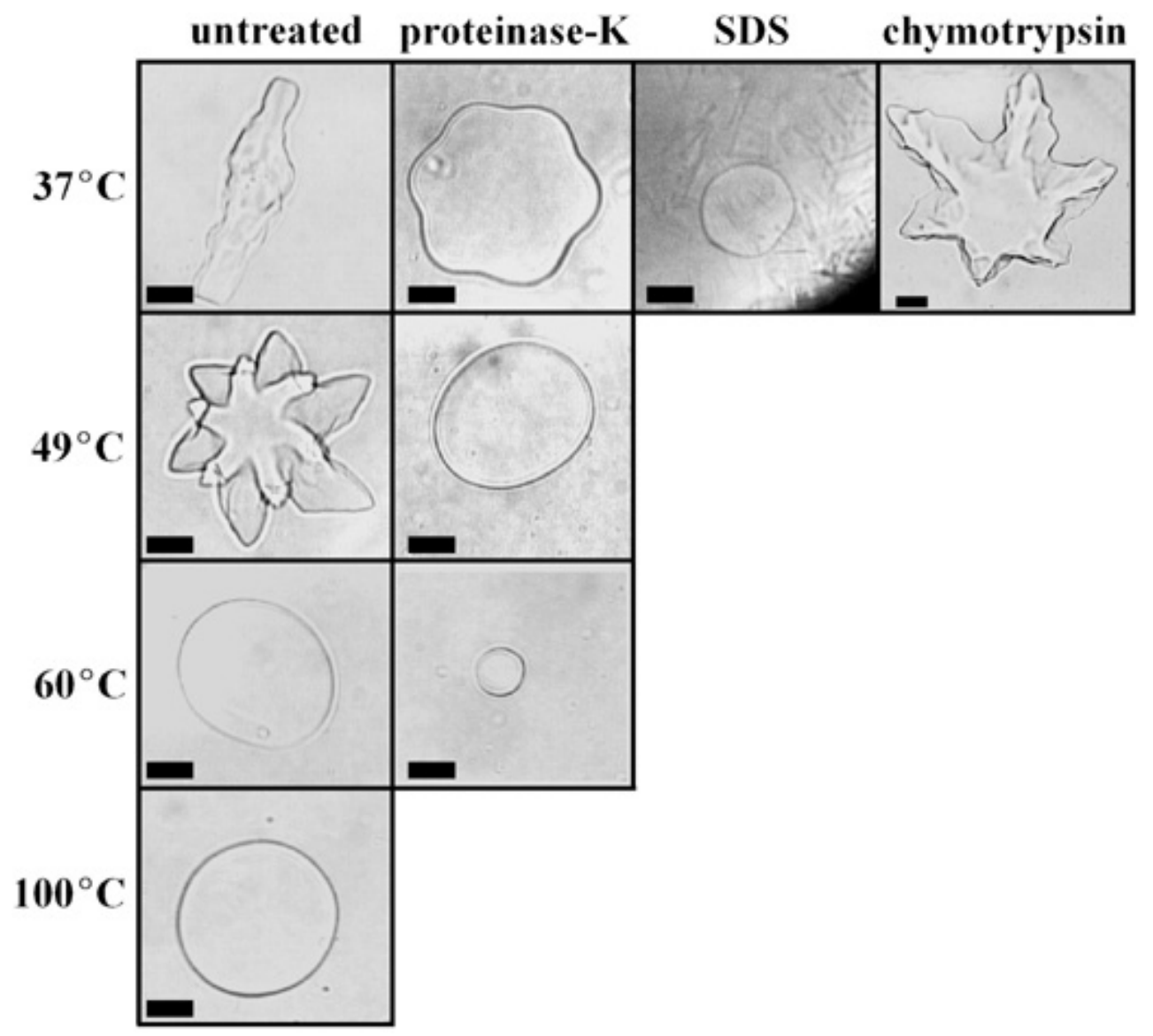

Fig. 5. Antifreeze activity of Typhula phacorrhiza isolate Tp 94614 subjected to different degradative treatments. Samples were subjected to heating $\left(37^{\circ} \mathrm{C}\right.$ for $1 \mathrm{~h}$, $49^{\circ} \mathrm{C}$ for $1 \mathrm{~h}, 60^{\circ} \mathrm{C}$ for $2 \mathrm{~h}$, or $100^{\circ} \mathrm{C}$ for $\left.2 \mathrm{~min}\right)$ or treated with proteinase $\mathrm{K}\left(3 \mathrm{mg} \mathrm{ml} l^{-1}\right.$ at $37^{\circ} \mathrm{C}$ for $2 \mathrm{~h}, 49^{\circ} \mathrm{C}$ for $3 \mathrm{~h}$, and $60^{\circ} \mathrm{C}$ for $\left.1 \mathrm{~h}\right)$, sodium dodecyl sulfate $\left(10 \mathrm{mg} \mathrm{ml}^{-1}\right.$ at $37^{\circ} \mathrm{C}$ for $3 \mathrm{~h}$ ), or chymotrypsin $\left(3 \mathrm{mg} \mathrm{ml}^{-1}\right.$ at $37^{\circ} \mathrm{C}$ for $3 \mathrm{~h}$ ), and then assayed for antifreeze activity as described in text. The ice crystal from the untreated $37^{\circ} \mathrm{C}$ control is shown with the $c$-axis parallel to the plane of the page. All other crystals are presented with the $c$-axis normal to the plane of the page. Magnification bars represent $10 \mu \mathrm{m}$. 
vival in central and northern Alberta. Can. J. Plant Pathol. 11:291-296.

10. Gaudet, D. A., and Laroche, A. 1998. Winter survival of cereals parasitized by snow mold. Pages 331-342 in: Plant Cold Hardiness. P. H. Li and T. H. Chen, eds. Plenum Press, New York.

11. Griffith, M., Ala, P., Yang, D. S. C., Hon, W. C., and Moffatt, B. A. 1992. Antifreeze protein produced endogenously in winter rye leaves. Plant Physiol. 100:593-596.

12. Griffith, M., and Antikainen, M. 1996 Extracellular ice formation in freezing tolerant plants. Adv. Low-Temp. Biol. 3:107-139.

13. Griffith, M., Glick, B. R., Xu, H., Sun, X. Y., Teijo, M. H., and Kaarina, P. M. 1997. Antifreeze proteins in overwintering plants and bacteria. Pages 181-188 in: International Workshop on Plant-Microbe Interactions at Low Temperature Under Snow. A. Nishimune and N. Iriki, eds. Hokkaido National Agricultural Experiment Station, Sapporo, Japan.

14. Gurion-Sherman, D., and Lindow, S. E. 1993. Bacterial ice nucleation: Significance and molecular basis. FASEB (Fed. Am. Soc. Exp. Biol.) J. 7:1338-1343.

15. Herbert, R. A. 1986. The ecology and physiology of psychrophilic microorganisms. Pages 1-23 in: Microbes in Extreme Environments. R. A. Herbert and G. S. Codd, eds. Academic Press, New York.

16. Hsiang, T., Matsumoto, N., and Millett, S. M. 1999. Biology and management of Typhula snow molds of turfgrass. Plant Dis. ?:788-798.

17. Kieft, T. L. 1988. Ice nucleation activity in lichens. Appl. Environ. Microbiol. 54:1678-1681.

18. Knight, C. A., DeVries, A. L., and Oolman, L. D. 1984. Fish antifreeze protein and the freezing and recrystallization of ice. Nature 208:295-296.

19. Knight, C. A., Driggers, E., and DeVries, A. L. 1993. Adsorption to ice of fish antifreeze glycopeptides 7 and 8. Biophys. J. 64:252-259.

20. Knight, C. A., and Duman, J. G. 1986. Inhibition of recrystallization of ice by insect thermal hysteresis proteins: A possible cryoprotective role. Cryobiology 23:252-262.

21. Laroche, A., Gaudet, D. A., Schaalje, G. B., Erickson, R. S., and Ginns, J. 1995. Grouping and identification of low temperature basidiomycetes using mating, RAPD and RFLP analyses. Mycol. Res. 99:297-310.

22. Lee, Jr., R. E., Lee, M. R., and Strong-Gunderson, J. M. 1993. Review of insect cold-hardiness and ice nucleating active: Microorganisms including their potential use for biological control. J. Insect Physiol. 39:1-12.

23. Levitt, J. 1980. Responses of Plant to Environmental Stresses. Vol. 1.
Academic Press, New York

24. Lindow, S. E. 1983. The role of bacterial ice nucleation in frost injury to plants. Annu. Rev. Phytopathol. 21:363-384.

25. Maki, L. R., Galyan, E. L., Chang-Chien, M. M., and Caldwell, D. R. 1974. Ice nucleation induced by Pseudomonas syringae. Appl. Microbiol. 28:456-459.

26. Nakajima, T., and Abe, J. 1994. Development of resistance to Microdochium nivale in winter wheat during autumn and decline of the resistance under snow. Can. J. Bot. 72:1211-1215.

27. Newsted, W. J., Polvi, S., Papish, B., Kendall, E., Saleem, M., Koch, M., Hussain, A., Cutler, A. J., and Georges, F. 1994. A low molecular weight peptide from snow mold with epitopic homology to the winter flounder antifreeze protein. Biochem. Cell Biol. 72:152-156.

28. Oke, T. R., and Hannell, F. G. 1966. Variations of temperature within a soil. Weather 21:21-28.

29. Pouleur, S., Richard, C., Martin, J. G., and Antoun, H. 1992. Ice nucleation activity in Fusarium acuminatum and Fusarium avenaceum. Appl. Environ. Microbiol. 38:2960-2964.

30. Schneider, E. F., and Seaman, W. L. 1986. Typhula phacorrhiza on winter wheat. Can. J. Plant Pathol. 8:269-276.

31. Sicheri, F., and Yang, D. S. C. 1995. Ice-binding structure and mechanism of an antifreeze protein from winter flounder. Nature 375:427-431.

32. Smith, J., Jackson, N., and Woolhouse, A. 1989. Fungal Diseases of Amenity Turf Grasses, 3rd ed. Spon, New York.

33. Storey, J. M., and Storey, K. B. 1985. Triggering of cryoprotectant synthesis by the initiation of ice nucleation in the freeze tolerant frog, Rana. sylvatica. J. Comp. Physiol. B 156:191-195.

34. Storey, K. B., and Storey, J. M. 1990. Frozen and alive. Sci. Am. 263(6): 92-97.

35. Urrutia, M. E., Duman, J. G., and Knight, C. A. 1992. Plant thermal hysteresis proteins. Biochem. Biophys. Acta 1121:199-206.

36. Vali, G. 1971. Quantitative evaluation of experimental results on the heterogeneous freezing nucleation of supercooled liquids. J. Atmos. Sci. 28:402-409.

37. Wu, C., Hsiang, T., Yang, L., and Liu, L. 1998. Efficacy of Typhula phacorrhiza as a biocontrol agent of grey snow mould of creeping bentgrass. Can. J. Bot. 76:1276-1281.

38. Zachariassen, K. E., and Hammel, H. T. 1976. Nucleating agents in the hemolymph of insects tolerant to freezing. Nature 262:285-287. 